\title{
THEORITICAL REVIEW: TEORI PEMASARAN HIJAU
}

\author{
Oleh: \\ Rina Sari Qurniawati \\ Dosen Tetap STIE AMA Salatiga
}

\begin{abstract}
Abstrak
Selama beberapa dekade terakhir, kelestarian lingkungan telah meningkat di puncak agenda politik internasional dan telah diakui sebagai pendorong utama inovasi. Akibatnya, jumlah perusahaan yang mengembangkan produk hijau telah berkembang pesat dan konsumen telah menunjukkan minat yang meningkat terhadap produk ini. Pemasaran produk hijau memerlukan pendekatan yang berbeda daripada memasarkan produk non-hijau (mis., Untuk melawan prioritas konsumen untuk kepentingan pribadi dan fokus pada jangka pendek vs. jangka panjang).

Dengan demikian, memahami karakteristik utama produk hijau, mengidentifikasi faktor-faktor yang mempengaruhi harga dan kesediaan konsumen untuk membayar lebih banyak untuk mereka, saluran penjualan dan alat promosi (4Ps pemasaran hijau) akan sangat berguna bagi perusahaan yang bertujuan merancang, mengembangkan dan memasarkan. produk hijau Untuk alasan ini, sangat memahami Green Marketing akan mendorong, di satu sisi, menghasilkan lebih banyak produksi melalui pengembangan produk hijau dan, di sisi lain, konsumsi berkelanjutan melalui pemasaran yang sukses di dalamnya. Pekerjaan saat ini mencoba menyoroti pentingnya adanya komitmen perusahaan yang benar untuk melindungi lingkungan di balik komunikasi hijau yaitu, kesadaran ekologis harus menjadi salah satu nilai yang menentukan budaya organisasi.
\end{abstract}

Kata kunci: Pemasaran hijau, 4P, Green marketing mix, Insentif

\section{PENDAHULUAN}

Pada tahun 1970-an perilaku peduli lingkungan dikenal sebagai “environmentalism”, sedangkan mulai tahun 1990-an dikenal sebagai “Green" dimana tekanan utama masalah pokok pada sosial, ekonomi, teknis, atau system 73lter daripada hanya permasalahan lingkungan saja. Lebih dari itu, fokusnya sekarang pada tataran global dibandingkan dengan permasalahan lingkungan secara lokal. Pesan gerakan peduli lingkungan fokus hanya pada pandangan jalan satu jalur yang berdampak pada lingkungan masyarakat dan bisnis. Akan tetapi, pergerakan hijau lebih aktif dalam

Theoritical Review: Teori Pemasaran Hijau (Rina Sari Qurniawati) 
mempromosikan sisi lain dari persamaan yang merupakan dampak dari lingkungan masyarakat dan bisnis (Tantawi, 2009). Istilah "Hijau" biasanya digunakan secara bergantian dengan "pro-lingkungan" (Shrum et al,. 1995) dan "lingkungan” (Mostafa, 2007). Akan tetapi karena perbedaan definisi dari lingkungan, istilah ini tidak terlalu tepat akan tetapi biasanya digunakan untuk mengindikasikan kepedulian akan lingkungan hidup (udara, air, dan tanah) (Shrum et al,. 1995).

Belakangan ini, kebanyakan konsumen telah sadar bahwa perilaku pembelian mereka mempunyai dampak langsung terhadap timbulnya berbagai masalah lingkungan. Konsumen beradaptasi dengan situasi baru yang mengancam ini dengan cara mempertimbangkan isu-isu lingkungan ketika mereka belanja. Cara-cara yang dilakukan misalnya, mengecek apakah produk yang ia beli mengandung bahan yang dapat di daur ulang dan hanya membeli barang yang merupakan produk ramah lingkungan (semprot rambut bebas CFC, penyaring kopi tanpa pemutih). Mungkin bukti yang paling meyakinkan satu bentuk dukungan terhadap tumbuhnya perilaku konsumen yang peduli terhadap lingkungan adalah meningkatnya jumlah individual yang sudi untuk membayar lebih untuk mendapatkan produk yang ramah lingkungan (Laroche et al., 2001)

Ada berapa fakta yang dapat dipertimbangkan, bahwa kebanyakan pasar dunia barat telah dipengaruhi oleh perilaku konsumen ramah lingkungan, yang berarti perilaku yang mencerminkan kepedulian tentang efek-efek dari pabrik dan konsumsi pada lingkungan yang alami. Selain adanya perubahan 74lter, lebih dari satu dekade yang lalu banyak perusahaan mulai merasakan adanya dampak dari tekanan pasar, seperti kebiasaan pembelian yang berubah pada konsumen yang berorientasi pada lingkungan dan perilaku pemboikotan yang mengakibatkan adanya laporan ke media massa dan tekanan pada aktivitas kelompok. Seperti diketahui bahwa lebih dari 70 persen konsumen ada kalanya mempertimbangkan isu-isu lingkungan pada perilaku pembelian mereka (Wegner, 1997).

Konsep Pemasaran Hijau berevolusi secara signifikan sejak pertama kali didefinisikan oleh Hennion and Kinnear (1976, hal 1) yaitu "peduli dengan semua aktivitas pemasaran yang membantu menimbulkan masalah lingkungan dan yang dapat memberikan pemulihan bagi masalah lingkungan" .Pemasaran hijau terdiri dari tindakan yang ditujukan kepada semua konsumen, dan menggabungkan berbagai aktivitas 
pemasaran (misalnya, harga, perencanaan, proses, produksi, promosi, dan orang-orang) yang dirancang untuk menunjukkan tujuan perusahaan untuk meminimalkan dampak lingkungan dari produk dan layanannya (Groening, Sarkis, dan Zhu, 2018).

Pada tahun 1975, American Marketing Association memperkenalkan istilah pemasaran hijau melalui sebuah lokakarya tentang "Pemasaran Ekologis". Pemasaran hijau juga disebut pemasaran lingkungan, pemasaran ekologis, pemasaran sosial, dan pemasaran berkelanjutan. Ini adalah konsep yang luas dengan tiga komponen kunci (Polonsky, 1994): (1) sub set pemasaran, (2) mengevaluasi aktivitas positif dan 75lternat; (3) mengkaji berbagai isu lingkungan. Definisi konseptual ini hanya satu dari banyak untuk pemasaran hijau. Konseptualisasi lainnya meliputi:

a. Komitmen oleh organisasi yang berfokus pada produk ramah lingkungan dan ramah lingkungan (Kinoti, 2011).

b. Memanfaatkan 4P (produk, harga, tempat, promosi) agar tidak menimbulkan kerusakan pada lingkungan (Dibb et al., 2005).

c. Proses manajerial pemasaran bertanggung jawab atas persyaratan pelanggan dan masyarakat secara menguntungkan dan berkelanjutan (Peattie, 2001)

Tabel 1

Perbedaan Antara Pemasaran Tradisional dengan Pemasaran Hijau

\begin{tabular}{|c|c|c|}
\hline Faktor Pembeda & Pemasaran Tradisional & Pemasaran Hijau \\
\hline Pihak yang terlibat & Perusahaan dan konsumen & $\begin{array}{l}\text { Perusahaan, konsumen, dan } \\
\text { lingkungan }\end{array}$ \\
\hline Tujuan & $\begin{array}{l}\text { 1. Kepuasan pelanggan } \\
\text { 2. Kepuasan tercapainya } \\
\text { tujuan perusahaan }\end{array}$ & $\begin{array}{l}\text { Kepuasan pelanggan } \\
\text { 2. Kepuasan tercapainya tujuan } \\
\text { perusahaan } \\
\text { 3. Meminimalisir dampak } \\
\text { ekologi }\end{array}$ \\
\hline $\begin{array}{ll}\text { Tanggung } & \text { jawab } \\
\text { perusahaan } & \end{array}$ & Tanggung jawab ekonomi & Tanggung jawab sosial \\
\hline $\begin{array}{l}\text { Jangkauan keputuasan } \\
\text { pemasaran }\end{array}$ & $\begin{array}{l}\text { Dari pembuatan } \\
\text { pemakaian produk }\end{array}$ & $\begin{array}{l}\text { Keseluruhan rantai nilai produk } \\
\text { dari perolehan } \\
\text { bahan mentah sampai pasca } \\
\text { konsumsi }\end{array}$ \\
\hline Tuntutan ekologi & Persyaratan resmi & $\begin{array}{l}\text { Melebihi peraturan: didesain } \\
\text { untuk lingkungan }\end{array}$ \\
\hline
\end{tabular}

Sumber: Chamorro dan Banegil (2005) 
Seperti dapat dilihat pada Tabel 1, ada perbedaan penting dalam cara berpikir antara pemasaran tradisional dan hijau. Namun, sama seperti apa yang terjadi ketika menerapkan filosofi pemasaran, menerapkan filosofi di balik pemasaran hijau tidak dapat dicapai dengan hanya membentuk departemen pemasaran untuk menerapkan teknik pemasaran hijau. Penghormatan terhadap lingkungan perlu mencakup semua perilaku di seluruh organisasi, tidak hanya 76lternat komersial (Ottman, 1993, 1998; Coddington, 1993; McDonagh dan Prothero, 1993; Peattie and Charter, 1994; Sheth and Parvatiyar, 1995; Wasik, 1996; Polonsky et al., 1997; Barnerjee, 1999; Fuller 1999; Polonsky dan Rosenberger, 2001). Selain itu, agar seluruh organisasi memperhatikan dampak lingkungan dari aktivitas mereka, lingkungan harus menjadi salah satu nilai penentu budaya organisasi perusahaan.

Konsep dan lingkup pemasaran hijau jauh lebih luas, karena memang untuk pemasaran pada umumnya. Pertama, pemasaran hijau seharusnya tidak hanya terbatas pada kebijakan komunikasi, aspek ekologi perlu dimasukkan ke dalam semua bidang fungsional pemasaran. Kedua, pemasaran hijau tidak boleh dipahami hanya sebagai serangkaian prosedur, aktivitas dan teknik untuk merancang dan mengkomersilkan produk hijau. Ini juga harus dianggap sebagai filosofi yang memandu perilaku organisasi wanita.Perbedaan antara pemasaran tradisional dengan pemasaran hijau.

Mengadaptasi model Kotler (1995) pada tingkat produk hijau, Chamorro dan Banegil (2005) membedakannya menjadi tiga tingkat, yaitu

a. Produk hijau dasar: pabrikan hanya mempertimbangkan karakteristik produk dalam tahap penggunaan / konsumsi dan pasca konsumsi.

b. Produk hijau yang diperluas: bila atribut ekologis juga dipertimbangkan dalam proses pembuatannya.

c. Produk hijau keseluruhan atau penawaran hijau: bila variabel ekologi dimasukkan ke dalam semua aktivitas internal perusahaan (keuangan, pembelian, sumber daya manusia, dsb.) dan perilaku lingkungan organisasi yang terkait dengan perusahaan (pemasok, distributor, entitas keuangan) tidak bertentangan dengan kebijakan dan prinsip. 


\section{STRATEGI PEMASARAN HIJAU DAN GREEN MARKETING MIX}

Strategi pemasaran memerlukan empat langkah yaitu: segmentasi, targeting, positioning dan diferensiasi (Kotler dan Armstrong, 2014). Melalui segmentasi dan penargetan, perusahaan mengidentifikasi kelompok atau kelompok konsumen untuk dilayani. Selain mengembangkan produk yang lebih berkelanjutan, perusahaan harus tampil lebih berkelanjutan sendiri. Merek hijau dapat diposisikan melalui berbagai atribut yang akan berkontribusi untuk membedakannya dari pesaing. Posisi ini dapat didasarkan pada atribut produk fungsional atau emosional (Hartmann et al., 2005). Strategi positioning berdasarkan karakteristik fungsional produk dapat ditingkatkan dengan manfaat lingkungan yang berasal dari proses produksi atau penggunaan produk (Peattie, 1995).

Banyak penelitian menyoroti bahwa segmentasi pasar tradisional tidak sesuai untuk pemasaran hijau. Straughan dan Roberts (1999), misalnya, menemukan bahwa kriteria psikografis lebih efektif daripada eksperimen demografis untuk segmentasi hijau, yang menyoroti bahwa efektivitas yang dirasakan konsumen, kepedulian lingkungan, dan 77 lternat adalah 77 lternati yang relevan dengan perilaku konsumen yang sadar lingkungan. Rex dan Baumann (2007) menyoroti bahwa pemasaran hijau harus dipikirkan kembali, dari menargetkan konsumen hijau dengan produk hijau menjadi memperluas konsumen yang ditargetkan dengan memasukkan fitur hijau sebagai salah satu dari banyak karakteristik produk.

Seperti dilansir Banyte dkk. (2010a), Ottman dan Reilly (1998) mengidentifikasi lima kelompok konsumen sesuai dengan keinginan mereka untuk berkontribusi terhadap perlindungan lingkungan (konsumen hijau yang setia, konsumen hijau yang kurang setia,

konsumen yang berkembang terhadap konsumen hijau dan konservatif yang tidak mau berubah, konsumen sama sekali tidak mau berubah).

Peattie (1995, hal 181) mendefinisikan suatu produk sebagai 'hijau' ketika kinerja lingkungan dan kemasyarakatannya, baik dalam produksi, penggunaan dan pembuangan, meningkat secara signifikan dibandingkan dengan penawaran produk konvensional atau kompetitif. Kualitas Produk Hijau harus berharga dan dapat dipahami. Dalam kategori 
produk di mana atribut terkait kekuatan (seperti "tahan lama") dan keberlanjutanakan dinilai, karena produk hijau sering dianggap lebih aman, lebih sehat, dan lebih lembut daripada produk lainnya (Luchs et al., 2010) . Kotler dan Amstrong (322014) menyatakan bahwa kemasan adalah komponen kunci dari sebuah produk dan kemasan berkelanjutan adalah kualitas yang paling diminta untuk Produk Hijau. Sustainable Packaging Alliance (2010) mendefinisikan kemasan berkelanjutan sebagai sesuatu yang efektif (memenuhi persyaratan fungsional dengan dampak lingkungan dan sosial yang minimal), efisien (dirancang untuk menggunakan 78ltern dan bahan secara efisien selama siklus hidup produk), siklik (menggunakan bahan-bahan terbarukan dan daur ulang), 781ternat (tidak mencemari dan tidak beracun).

Green Pricing / harga hijau dapat didefinisikan sebagai penetapan harga untuk produk hijau yang mengimbangi kepekaan konsumen terhadap harga terhadap kesediaan mereka untuk membayar lebih untuk kinerja lingkungan produk (Grove et al., 1996). Istilah "harga premium" dalam konteks hijau mengacu pada biaya tambahan yang harus dibayar konsumen dibandingkan dengan 78 lternative tradisional untuk memperoleh produk dengan kinerja lingkungan yang lebih tinggi (Peattie, 2001).

Prothero dkk. (1997) mengklaim bahwa strategi hijau yang sukses bergantung pada komunikasi yang baik. Periklanan hijau harus menyoroti manfaat lingkungan, mempromosikan gaya hidup yang berkelanjutan, meningkatkan citra hijau merek, dan mengurangi informasi (Smith, 2005). Leonidou dkk. (2011) mengamati peningkatan jumlah rincian iklan hijau dari waktu ke waktu, dengan menyoroti hal itu dapat disebabkan oleh beberapa alasan: investasi berat yang dilakukan oleh banyak perusahaan dalam peralatan dan proses lingkungan; kebutuhan untuk membedakan diri dari pesaing dengan mengkomunikasikan citra hijau; keragaman masalah lingkungan, membutuhkan komunikasi yang lebih luas dan mendalam.

Saat ini konsumen jarang secara aktif mencari produk hijau, keputusan tentang bagaimana dan di mana membuat produk hijau tersedia sangat penting; Distribusi ceruk tampaknya tidak menjadi pilihan yang baik untuk produk hijau karena konsumen harus melihat tampilan produk hijau di mana mereka berbelanja (Mishra dan Sharma, 2012). Hal lain yang perlu dipikirkan pemasar dengan hati-hati adalah bahwa menjual produk 
hijau tidak sama dengan menjual produk standar, karena karakteristik produk baru, persyaratan baru dari pelanggan, peraturan baru. Untuk alasan ini, tim pemasar berdedikasi yang akan mengelola produk dari produksi ke titik penjualan dan, kemudian, kepada pelanggan dapat meningkatkan kinerja distribusi (Tomasin et al., 2013).

Tabel 2

Strategi Pemasaran Hijau dan Green Marketing Mix

\begin{tabular}{|c|c|c|}
\hline \multirow{4}{*}{ Strategi Pemasaran Hijau } & Product & $\begin{array}{l}\text { 1. Produk mempunyai manfaat pada } \\
\text { konsumen dan lingkungan } \\
\text { 2. Kemasan hijau merupakan komponen } \\
\text { kunci dalam sebuah produk } \\
\text { 3. mengevaluasi dan menghilangkan } \\
\text { kesenjangan persepsi dalam kinerja } \\
\text { dibandingkan dengan produk } \\
\text { tradisional }\end{array}$ \\
\hline & Price & $\begin{array}{l}\text { Kerelaan untuk membayar harga } \\
\text { premium/lebih mahal untuk produk } \\
\text { hijau }\end{array}$ \\
\hline & Promotion & $\begin{array}{l}\text { 1. secara jelas mengkomunikasikan } \\
\text { produk hijau dan karakteristik merek } \\
\text { untuk mengurangi asimetri informasi } \\
\text { 2. label dan kemasan hijau sebagai } \\
\text { pengidentifikasi dari produk hijau } \\
\text { 3. pesan generik dan menyesatkan dapat } \\
\text { menghasilkan greenwashing }\end{array}$ \\
\hline & Place & $\begin{array}{l}\text { Siklus konsumsi dengan lup tertutup } \\
\text { (close-loop) dapat mengurangi biaya dan } \\
\text { meningkatkan pelayanan }\end{array}$ \\
\hline \multirow{4}{*}{ Green Marketing Mix } & $\begin{array}{ll}\begin{array}{l}\text { Diferensiasi } \\
\text { (Differentiation) }\end{array} & \text { Pasar } \\
\end{array}$ & $\begin{array}{l}\text { "Hijau" sebagai tuas untuk mencapai } \\
\text { diferensiasi dan keunggulan kompetitif }\end{array}$ \\
\hline & Posisi Pasar (Positioning) & $\begin{array}{l}\text { - Posisi merek sangat relevan } \\
\text { - Posisi fungsional atau emosional }\end{array}$ \\
\hline & $\begin{array}{l}\text { Penetapan Target Pasar } \\
\text { (Targeting) }\end{array}$ & $\begin{array}{l}\text { - Produk hijau untuk konsumen hijau } \\
\text { - Memperluas konsumen yang } \\
\text { ditargetkan dengan memasukkan fitur } \\
\text { hijau pada produk konvensional }\end{array}$ \\
\hline & $\begin{array}{l}\text { Segmentasi } \\
\text { (Segmentation) }\end{array}$ & $\begin{array}{l}\text { Dua dimensi utama } \\
\text { - Konsumen yang pro hijau } \\
\text { - Persepsi pembelian }\end{array}$ \\
\hline
\end{tabular}

Sumber: Dangelico dan Vocalelli (2017) 


\section{KONTEKS PASAR DAN NON-PASAR}

Perusahaan dapat memilih untuk menghijaukan sistem, kebijakan dan produk mereka karena tekanan ekonomi dan nonekonomi dari konsumen, mitra bisnis mereka (lingkungan pasar), regulator, kelompok masyarakat dan pemangku kepentingan lainnya (lingkungan non pasar). Baron (1995) berpendapat, lingkungan pasar dan non-pasar saling mempengaruhi satu sama lain. Dengan demikian, perusahaan perlu menerapkan pendekatan terpadu terhadap pasar mereka (dalam konteks konsumen rumah tangga dalam diskusi di bawah) dan strategi non-pasar. Misalnya, dalam mengadopsi kebijakan pemasaran hijau, perusahaan mungkin menghadapi banyak tantangan seperti memutuskan antara sikap konsumen dan perilaku aktual, dan keengganan mereka untuk membayar premi produk hijau. Ini sebagian berakar pada skeptisisme konsumen terhadap klaim lingkungan. Dengan demikian, isu peraturan dan kebijakan mengenai klaim lingkungan (seperti pelabelan atau periklanan) yang muncul di arena non-pasar mungkin berpengaruh pada strategi pasar perusahaan.

\section{a. Konsumen: Sikap Vs Perilaku}

Beberapa peneliti percaya bahwa konsumen bersedia membayar premi untuk produk hijau karena konsumen sering memprioritaskan atribut hijau atas atribut produk tradisional seperti harga dan kualitas. Namun, klaim dan sikap semacam itu mungkin tidak selalu diterjemahkan ke dalam perilaku yang sebenarnya (McGuire, 1985). Salah satu alasannya adalah tekanan sosial menjadi 'hijau' (Ritchie dan McDougall, 1985). Akibatnya, terlepas dari klaim tentang kepedulian terhadap lingkungan alam, pasar konsumen massal untuk produk hijau dalam kebanyakan kategori belum dikembangkan. Perusahaan sering perlu mengenakan harga premium untuk produk hijau. Tentu saja, jika produk hijau lebih murah dari produk lain, harga premium mereka tidak akan menjadi masalah bagi konsumen.

Prakash (2000) berpendapat bahwa tantangan utama bagi pemasar adalah untuk memahami apakah konsumen melihat pengukuhan perusahaan / produk sebagai faktor pendorong (kehadiran mereka mendorong konsumen untuk membeli produk tertentu; preferensi untuk suatu produk adalah peningkatan fungsi tingkat penghijauan) atau faktor kebersihan (ketidakhadiran mereka mungkin mengganggu konsumen, namun setelah 
ambang penghijauan yang rendah, preferensi untuk suatu produk bukanlah peningkatan fungsi tingkat penghijauan). Jika konsumen menyukai perusahaan dengan kebijakan hijau (misalnya, sertifikasi ISO 14001) atau produk hijau (misalnya, yang memiliki persentase input daur ulang lebih tinggi disukai), kebijakan / produk hijau adalah faktor pendorong.

Para manajer memiliki justifikasi ekonomi untuk memastikan bahwa perusahaan / produk mereka lebih hijau daripada pesaing mereka. Namun, jika konsumen tidak terlalu peduli dengan siapa yang lebih hijau, namun mereka menghukum perusahaan yang melanggar undang-undang lingkungan atau memancarkan racun dalam tingkat tinggi, kehijauan adalah variabel kebersihan - 33\% orang dewasa mengaku telah menghindari membeli produk, setidaknya sesekali, dari perusahaan dengan catatan lingkungan yang buruk (Ottman, 1996). Jika demikian, maka tugas manajerial adalah mematuhi undangundang lingkungan, untuk menghindari masalah dengan regulator dan untuk menghindari pers buruk dengan melakukan minimal inisiatif kepatuhan.

\section{b. Tekanan dari Stakeholder dan Kelembagaan}

Perusahaan dapat memilih untuk mengadopsi strategi pemasaran hijau karena alasan normatif dan tekanan dari lingkungan non-pasar mereka. Ekonom Neoklasik, termasuk ekonom lingkungan, memandang memaksimalkan kekayaan pemegang saham sebagai tujuan sosial perusahaan (Friedman, 1970). Sebaliknya, teori institusional berfokus pada dampak institusi non-pasar terhadap kebijakan perusahaan (Hoffman, 1997). Ini menunjukkan bahwa perusahaan tidak selalu memaksimalkan keuntungan; Kebijakan mereka sering mencerminkan tekanan eksternal untuk legitimasi. Untuk mendapatkan kepercayaan dari institusi eksternal, perusahaan dapat memiliki alasan kuat untuk menghijaukan produk / kebijakan mereka dan untuk memberikan informasi yang memadai dan dapat diverifikasi kepada konsumen mengenai hal-hal. ini.

Demikian pula, teori pemangku kepentingan menyarankan bahwa perusahaan harus (dan sering melakukan) merancang kebijakan yang mempertimbangkan preferensi beberapa pemangku kepentingan - pemangku kepentingan adalah 'kelompok atau individu yang dapat mempengaruhi atau dipengaruhi oleh pencapaian tujuan organisasi' (Freeman, 1984 , hal. 46). Dengan demikian, perusahaan akan menghijaukan produk / kebijakan / proses mereka dan mengungkapkan informasi yang memadai dan dapat dipercaya, jika 
pemangku kepentingan 'utama', internal atau eksternal, menuntutnya (untuk mengklasifikasikan pemangku kepentingan mengenai dimensi kekuasaan, legitimasi dan urgensi) .

Alasan strategis pemasaran hijau yang penting adalah dapat membantu perusahaan untuk menerapkan peraturan perintah dan kontrol yang sering merugikan keuntungan mereka (Fri, 1992), dan memungkinkan mereka membentuk peraturan masa depan, sehingga dapat memperoleh keuntungan penggerak pertama. Memenangkan standar produk dan proses yang ketat akan menarik bagi perusahaan yang berteknologi maju karena mereka dapat mengklaim dirinya berbudi luhur, dan pada saat yang sama, menaikkan biaya masuk saingan dengan anggapan bahwa standar yang lebih tinggi akan menghasilkan peraturan yang ketat.

\section{PERAN INSENTIF DAN FAKTOR STRUKTURAL}

Dilihat dari wawasan literatur ekonomi politik, literatur pemasaran memperdebatkan kemanjuran relatif pengorbanan tingkat individu (biaya langsung) versus pengorbanan kolektif (biaya tidak langsung). Alih-alih pengorbanan tingkat individu (membayar premi untuk produk hijau atau mengubah gaya hidup untuk mengurangi beban terhadap lingkungan), dari mana konsumen dapat memilih keluar, beberapa pemasar sosial menyukai pengorbanan kolektif atau biaya tidak langsung, yang darinya individu tidak dapat memilih keluar (Weiner, 1993). Diperkirakan bahwa dengan menyediakan konteks kelembagaan baru, pengorbanan kolektif semacam itu akan meyakinkan konsumen untuk mengubah gaya hidup mereka. Jika tujuannya adalah untuk mengurangi emisi gas rumah kaca, pengorbanan kolektif dapat terwujud sebagai pajak yang lebih tinggi (pajak energi), standar ketat (kode bangunan perumahan, standar efisiensi bahan bakar mobil) atau beberapa batasan kolektif lainnya yang mengenakan biaya atau berpotensi mengubah gaya hidup dari banyak orang. Selain mengurangi dilema tindakan kolektif, pengorbanan kolektif memberi konsumen tingkat kepercayaan yang lebih tinggi bahwa tindakan mereka akan membuat perbedaan.

Memilih keluar dari pengorbanan tingkat individu mungkin bukan satu-satunya cara bagi konsumen untuk mengungkapkan preferensi mereka. Literatur pemasaran juga meneliti arti penting atribut konsumen dan parameter struktural (lingkungan pasar, norma 
sosial dan institusi) dalam mendorong perilaku ramah lingkungan. Ada juga perdebatan tentang kemanjuran relatif faktor ekonomi dan nonekonomi dalam mendorong perubahan perilaku. Derksen dan Gartrell (1993) berpendapat bahwa variabel demografi menunjukkan asosiasi kecil dengan perilaku daur ulang dan konteks sosial adalah penentu utama: orang-orang yang memiliki akses ke program daur ulang menunjukkan tingkat daur ulang yang lebih tinggi daripada mereka yang tidak memiliki akses semacam itu. Sikap individu terhadap daur ulang tidak dapat mengatasi rintangan struktural; sikap hanya mempengaruhi perilaku jika individu memiliki akses mudah ke program daur ulang.

\section{DAFTAR PUSTAKA}

Chamorro A. dan T. M. Banegil (2005), “ Green Marketing Philosophy: A Study of Spanish Firm with Ecolabels," Corporate Social Responsibility and Environmental Management, 13, 11-24

Dangelico, R.M, dan D. Vocalelli (2017), “Green Marketing: An analysis of definitions, strategy steps, and tools through a systematic review of the literature", Journal of Cleaner Production, Volume 165, 1 November 2017, Pages 1263-1279

Dibb, S., Simkin, L., Pride, W. M., Ferrell, O. C., (2005), Marketing: Concepts and Strategies. Houghton Mifflin, hal.850.

Freeman RE (1984). Strategic Management: a Stakeholder Approach. Pitman: Boston, MA.

Friedman M. (1970). The social responsibility of business is to increase its profits. New York Times Magazine 13 September: 32-33, 122-126.

Fri RW (1992), "The corporation as a non-governmental organization," The Columbia Journal of World Business 27, 91-95.

Groening C, J. Sarkis, Q. Zhu (2017), “Green marketing consumer-level theory review: A compendium of applied theories and further research directions," In Journal of Cleaner Production, Volume 172, Pages 1848-1866

Hoffman AJ. (1997). From Heresy to Dogma. New Lexington: San Francisco, CA.

Kinoti, M. W. (2011), "Green marketing intervention strategies and sustainable development: a conceptual paper.”Int.J.Bus.Soc.Sci.2(23),263.

Theoritical Review: Teori Pemasaran Hijau (Rina Sari Qurniawati) 
Kotler Ph. (1995), Marketing Management. Prentice-Hall: Madrid.

Laroche, M., J. Bergeron, dan G. Barbaro-Forleo (2001), "Targeting Consumers Who Are Willing to Pay More for Environmentally Friendly Products," Journal of Consumer Marketing, Vol 18, No 6, pp. 503-520.

McGuire WJ. 1985. Attitudes and attitude change. In Handbook of Social Psychology, Lindzey G, Aronson E (eds). Random: New York; 233-346.

Mostafa, M.M. (2007), "Gender Differences in Egyptian Consumers' Green Purchase Behaviour: The Effects of Environmental Knowledge, Concern and Attitude," International Journal of Consumer Studies, Vol 31, pp. 220-229.

Ottman J. (1996). Green consumers not consumed by ecoanxiety. Marketing News 30: 13.

Peattie, K., (2001), Towards sustainability: the third age of green marketing, Mark. Rev. 2(2),129-146.

Polonsky, M.J., (1994), An introduction to green marketing. Electron. Green J. 1 (2).

Prakash A. (2000), Responsible Care: an assessment. Business and Society 39: 183-209.

Ritchie JRB, McDougall GHG. (1985), "Designing and marketing energy conservation policies and programs." Journal of Public Policy and Marketing 4: 14-32.

Shrum, L.J., J.A. McCarthy, and T.M. Lowrey (1994), “ Buyer Characteristics of The Green Consumer and Their Implication of Advertising Strategy," Journal of Advertising, Vol 24, No 2, pp. 71-82.

Weiner JL. (1993) "What makes people sacrifice their freedom for the good of their community?", Journal of Public Policy and Marketing 12: 244-260. 